\title{
PENYELESAIAN DEBITUR WAN PRESTASI ATAS OBYEK JAMINAN FIDUSIA YANG TELAH DIDAFTARKAN
}

\author{
Rahmat Hidayat, Soegianto Soegianto \\ Magister Hukum Universitas Semarang, Semarang
}

\begin{abstract}
ABSTRAK
Tujuan penelitian ini adalah untuk mengetahui dan menganalisa Penyelesaian debitur wanprestasi atas obyek jaminan fidusia yang telah didaftarkan. Perusahaan pembiayaan dalam pemberian kredit pada debitur sering kali mengalami persoalan terutama pada debitur yang wanprestasi, pinjam meminjam melalui lembaga pembiayaan dengan perjanjian baku antara perusahaan pembiayaan(kreditur) dengan debitur juga sering kali mengalami permasalahan,salah satunya atas ketidak pahaman terhadap peraturan perundangan yang ada,kondisi ekonomi dan karakter dari debitur sering kali melakukana tindakan yang di larang oleh undang-undang seperti memindah tangankan obyek jaminan fidusia. Permasalahan Penelitian ini adalah Penyelesaian debitur wanprestasi atas obyek jaminan fidusia yang telah didaftarkan sesuai dengan undang-undang No 42 tahun 199 tentang jaminan fidusia,dalam hal ini di terangkan tentang proses pendaftaran jaminan fidusia dan pelaksanaan eksekusi jaminan fidusia,bagaimana penyelesaian debitur wanprestasi atas obyek jaminan fidusia yang telah didaftarkan sesuai dengan undang-undang No 42 tahun 1999 tentang jaminanfidusia dan akibat hukumnya bagi debitur wanprestasi yang memindah tangankan obyek jaminan fidusia ke pada pihak ketiga sedangkan jaminan fidusianya sudah didaftarkan. Metode Penelitian dengan metode pendekatan yuridis normative. Kredit yang diberikan dengan jaminan fidusia berdasarkan kepercayaan terhadap debitur karena barang yang menjadi jaminan tetap berada dibawah tangan penguasaan debitur. Adapun hambatan yang sering terjadi pada saat debitur wanprestasi kreditur sering mengalami kesulitan pada saat akan melakukan eksekusi obyek jaminan fidusia dikarenakan objek jaminan fidusia tersebut sudah di pindah tangankan oleh debitur, padahal eksekusi merupakan bagian dari proses penyelesaian sengketa hukum sebagai upaya terakhir kreditur untuk merealisasikan haknya secara paksa jika debitur tidak secara sukarela memenuhi kewajibannya.
\end{abstract}

Kata Kunci : Jaminan Fidusia; eksekusi obyek; wanprestasi 
e-ISSN : 2621-4105

\title{
RESOLUTION OF DEBTOR DEFAULTS ON REGISTERED FIDUCIARY COLLATERAL OBJECTS
}

\author{
Rahmat Hidayat, Soegianto Soegianto \\ Master of Law, University of Semarang, Semarang
}

\begin{abstract}
The purpose of this research is to find out and analyze the settlement of debtor defaults on registered fiduciary collateral objects. Financing companies in granting credit to debtors often experience problems, especially on debtors who default, lending and borrowing through financing institutions with standard agreements between finance companies (creditors) with debtors also often experience problems, one of which is due to lack of understanding of existing laws and regulations, economic conditions and the character of the debtor often take actions that are prohibited by law such as transferring the object of fiduciary security.The problem of this research is the Settlement of defaults on debtor fiduciary objects that have been registered in accordance with law No. 42 of 199 concerning fiduciary guarantees, in this case explained about the process of registering fiduciary guarantees and the execution of fiduciary guarantees, how the settlement of default debtors on collateral objects fiduciary which has been registered in accordance with law No. 42 of 1999 concerning fiduciary collateral and its legal consequences for defaulted debtors who move the object of fiduciary collateral to a third party while the fiduciary guarantee has been registered. The research method is normative juridical approach. Credit granted with fiduciary collateral is based on the trust of the debtor because the collateral remains in the hands of the debtor. As for the obstacles that often occur when debtors default on creditors often have difficulty when executing fiduciary collateral because the fiduciary object has already been in the fiduciary collateral object. transferred by the debtor, even though the execution is part of the legal dispute settlement process as the creditor's last attempt to realize his rights by force if the debtor does not voluntarily fulfill his obligations.
\end{abstract}

Keywords: Fiduciary guarantee; execution objects; default performance 
e-ISSN : 2621-4105

\section{A. PENDAHULUAN}

Perusahaan pembiayaan mempunyai peranan yang besar dalam mendorong perekonomian nasional,pada umumnya perusahaan pembiayaan dalam menjalankan fungsinya sebagai pemberi pinjaman kredit kepada masyarakat berupa kredit pembiayaan kepada debitur.Pemberian kredit oleh perusahaan pembiayaan merupakan bisnis yang beresiko, terutama yang menyangkut dengan penyaluran dana kredit pada debitur.

Perjanjian pembiayaan kredit pada umumnya merupakan perjanjian baku antara perusahaan pembiayaan(kreditur) dengan debitur, Kepada debitur hanya diberi pilihan berupa " take it " or " leave it". Jika setuju dengan klausula perjanjian yang ditawarkan oleh pihak perusahaan pembiayaan maka terjadilah perjanjian kredit, tetapi jika tidak maka kredit tidak akan diberikan oleh perusahaan pembiayaan. Pada posisi demikian perusahaan pembiayaan berada pada tempat yang lebih kuat bila dilihat dari sisi bisnis, tetapi bila dilihat dari tujuan pemberian kredit untuk menunjang pembangunan ekonomi, maka posisi yang tidak seimbang demikian akan mendatangkan masalah. Keadaan demikian telah dirasakan oleh kalangan perusahaan pembiayaan dengan banyaknya kredit bermasalah atau kredit macet.Salah satu faktor yang menjadi penyebab kredit macet adalah besarnya nilai jaminan tidak sebanding dengan pinjaman,karakter dari debitur itu sndiri bahkan ada juga debitur yang mengalihkan obyek jaminannya apabila obyek jaminan tersebut merupakan benda bergerak.

Perjanjian pembiayaan kredit yang dilakukan oleh perusahaan Pembiayayaan dengan jaminan benda bergerak berupa kendaraan bermotor diikat dengan fidusia sebagaimana diatur dalam Undang-Undang Nomor 42 Tahun 1999 tentang Jaminan Fidusia. Namun, dalam prakteknya seringkali debitur menyalah gunakan kepercayaan kreditur yaitu dengan wanprestasi bahkan memeindahkan obyek jaminan fidusia. Ini yang sering jadi permasalahan antara perusahaan pembiayaan(kreditur) dengan debiturnya dalam hal ini bagaimana penyelesaian debitur wanprestasi atas obyek fidusia yang telah didaftarkan sesuai dengan undang 
-undang No 42 tahun 1999 tentang jaminan fidusia yang dilakukan perusahaan pembiayayaan sebagai kreditur terhadap debitur yang wanprestasi.

\section{B. PERMASALAHAN}

Berdasarkan uraian latar belakang sebagaimana yang telah dikemukakan diatas, maka permasalahan dalam penelitian ini adalah :

1. Bagaimana proses pendaftaran jaminan fidusia dan pelaksanaan eksekusi jaminan fidusia?

2. Bagaimana penyelesaian debitur wanprestasi atas obyek jaminan fidusia yang telah didaftarkan sesuai dengan undang-undang No 42 tahun 1999 tentang jaminan fidusia?

3. Bagaimana akibat hukumnya bagi debitur wanprestasi yang mengalihkan obyek jaminan fidusia ke pada pihak ketiga sedangkan jaminan fidusianya sudah didaftarkan ?

\section{METODE PENELITIAN}

Metode penelitian yang digunakan oleh penulis dalam menyusun penelitian ini adalah sebagai berikut:

1. Metode Pendekatan

Berdasarkan rumusan masalah dan tujuan penelitian, maka metode pendekatan yang digunakan adalah metode pendekatan yuridis normatif yaitu metode pendekatan dengan cara meneliti bahan pustaka dan data sekunder. ${ }^{1}$

Penelitian hukum normatif adalah penelitian hukum yang meletakan hukum sebagai sebuah bangunan sistem norma. ${ }^{2}$

2. Spesifikasi Penelitian

Spesifikasi yang digunakan dalam penelitian ini adalah deskriptif analisis. Menurut Ronny Hanitijo Soemitro, deskriptif analisis.

3. Jenis dan Sumber Data

\footnotetext{
${ }^{1}$ Soerjono Soekanto dan Sri Mamudji, 2004, Penelitian Hukum Normatif (Jakarta : Rajawal Pres), hlm.13

${ }^{2}$ Mukti Fajar ND dan Yulianto Achmad, 2013, Dualisme Penelitian Hukum Normatif \& Empiris (Yogyakarta : Pustaka Pelajar), hlm.34
} 
Sehubungan dengan metode pendekatan dalam penelitian ini adalah yuridis normatif, maka penelitian ini dilakukan dengan studi pustaka yang bersumber pada data sekunder.

4. Metode Pengumpulan Data

Data sekunder yang merupakan sumber utama dalam penelitian ini dikumpulkan dengan melakukan studi kepustakaan/ studi pusat dokumenter. Data sekunder dapat diperoleh di perpustakaan, pusat dokumentasi, arsip dan museum. ${ }^{3}$ Dengan demikian studi ini untuk mencari konsepsi-konsepsi, teori-teori, pendapatpendapat dan pemenuan-penemuan yang berhubungan dengan pokok permasalahan. $^{4}$

5. Metode Analisis Data

Penelitian ini bersifat analisis kualitatif, yaitu menggambarkan, menjelaskan, serta menganalisis sejumlah data sekunder yang telah diperoleh. Penjelasan terhadap data dilakukan dengan menggunakan teori-teori dan norma-norma hukum yang ada sedangkan keseluruhan data yang diperoleh disajikan secara kualitatif yaitu dalam bentuk uraian yang sistematis. ${ }^{5}$

\section{PEMBAHASAN}

\section{Proses pendaftaran jaminan fidusia dan pelaksanaan eksekusi jaminan fidusia.}

\section{A. Proses pendaftaran jaminan fidusia}

Pelayanan pendaftaran Jaminan Fidusia secara elektronik (online system). Dalam hal ini maka terbitlah PP No. 21 tahun 2015Pengaturan baru yang terdapat dalam Peraturan Pemerintah ini, antara lain:

a. Adanya kewajiban bagi Penerima Fidusia, kuasa atau wakilnya untuk memberitahukan penghapusan Jaminan Fidusia. Pemberitahuan penghapusan tersebut tidak dikenakan biaya. Dengan tidak adanya biaya yang dikenakan diharapkan Penerima Fidusia, kuasa atau wakilnya dapat melakukan

\footnotetext{
${ }^{3}$ Burhan Ashshofa. Metode Penelitian Hukum (Jakarta : Rineka Cipta), hlm. 104

${ }^{4}$ Ronny Hanitijo Soemitro. Metode Penelitian Hukum dan Jumitri (Yogyakarta :Ghalia Indonesia), hlm.98

${ }^{5}$ Soerjono Soekanto, Op.Cit,hlm.25
} 
pemberitahuan penghapusan Jaminan Fidusia tersebut dengan sukarela dan tanpa beban. Hal ini akan memudahkan bagi Kementerian Hukum dan Hak Asasi Manusia untuk melakukan pemantauan terhadap Jaminan Fidusia yang sudah berakhir atau akan berakhir jangka waktunya.

b. Besarnya biaya pembuatan akta Jaminan Fidusia ditentukan berdasarkan nilai penjaminan yangmengacu pada besarnya biaya pembuatan akta yang diatur dalam Pasal 36 ayat (3) Undang-Undang Nomor 30 Tahun 2004 tentang Jabatan Notaris sebagaimana telah diubah denganUndang-Undang Nomor 2 Tahun 2014 tentang Perubahan atas Undang-Undang Nomor 30 Tahun2004 tentang Jabatan Notaris

c. Adanya ketentuan bahwa seluruh data yang diisi dalam permohonan pendaftaran Jaminan Fidusia,permohonan perbaikan sertifikat Jaminan Fidusia, permohonan perubahan sertifikat JaminanFidusia, dan pemberitahuan penghapusan sertifikat Jaminan Fidusia secara elektronik sertapenyimpanan dokumen fisiknya menjadi tanggung jawab Penerima Fidusia, kuasa atau wakilnya.

d. Saat ini tidak hanya Notaris saja yang dapat mengakses pendaftaran Jaminan Fidusia. Pihak-pihak lain seperti multifinance maupun masyarakat dapat pula mengakses pendaftaran jaminan fidusia melalui www.ahu.go.id.

Menurut PP No. 21 tahun 2015 pasal 16 ${ }^{6}$, Permohonan pendaftaran Jaminan Fidusia, permohonan perbaikan sertifikat Jaminan Fidusia, permohonan perubahan sertifikat Jaminan Fidusia, dan pemberitahuan penghapusan sertifikat Jaminan Fidusia diajukan oleh Penerima Fidusia, kuasa atau wakilnya kepada Menteri melalui sistem pendaftaran Jaminan Fidusia secara elektronik.

1. Permohonan pendaftaran Jaminan Fidusia

2. Perubahan sertifikat

3. Penghapusan Jaminan Fidusia

${ }^{6} \mathrm{PP}$ No. 21 tahun 2015 pasal 1 
Apabila Jaminan Fidusia hapus karena hapusnya utang yang dijamin dengan fidusia, pelepasan hak atas Jaminan Fidusia oleh Penerima Fidusia; atau musnahnya benda yang menjadi objek Jaminan Fidusia, maka Penerima Fidusia, kuasa atau wakilnya, wajib memberitahukan kepada Menteri dalam jangka waktu paling lama 14 (empatbelas) hari terhitung sejak tanggal hapusnya Jaminan Fidusia.

Adapun mengenai jenis dan tarif atas jenis penerimaan negara bukan pajak(PNBP) diatur dalam PP No 28 tahun 2019 disitu menerangkan tentang jenis dan tarif atas jenis penerimaan negara bukan pajak(PNBP) yang berlaku pada Kementrian Hukum dan Hak Asasi Manusia.

\section{B. Pelaksanaan eksekusi jaminan fidusia.}

a) Eksekusi yang diatur dalam Undang-Undang Nomor 42 Tahun 1999 tentang Jaminan Fidusia.

Pelaksanaan eksekusi jaminan fidusia diatur di dalam pasal 29 sampai dengan Pasal 34 Undang-Undang Nomor 42 Tahun 1999 Tentang Jaminan Fidusia dan Berdasarkan ketentuan pasal 21 sampai dengan pasal 23 dan pasal 51 Peraturan Otoritas Jasa Keuangan Nomor 29/POJK.05/2014 tentang Penyelenggaraan Usaha Perusahaan Pembiayaan.

Ojk telah melakukan revice atas POJK Nomor 29/POJK.05/2014 di lakukan revice ke POJK No. 35 tahun 2018 dan No. 10 tahun 2019 tentang penyelenggaraan usaha perusahaan pembiyaan.

b) Eksekusi Jaminan Fidusia Berdasarkan Peraturan Kapolri No. 8 tahun 2011

Untuk proses pengamanan eksekusi atas jaminan fidusia ini tercantum dalam pasal 7 Peraturan Kapolri No. 8 tahun 2011, dimana permohonan pengamanan eksekusi tersebut harus diajukan secara tertulis oleh penerima jaminan fidusia atau kuasa hukumnya kepada Kapolda atau Kapolres tempat eksekusi dilaksanakan. 
2. Penyelesaian debitur wanprestasi atas obyek jaminan fidusia yang telah didaftarkan sesuai dengan undang-undang No 42 tahun 1999 tentang jaminan fidusia

Ketika debitur sudah mengalami gagal bayar dan kreditnya bermasalah, maka perusahaan pembiayaan akan melakukan tindakan-tindakan penyelamatan kredit. Tindakan penyelamatan kredit yang dilakukan oleh saudara Kadarusman yang menjabat sebagai Claster Collection Headipada divisi Collection PT Adira Dinamika Fulti Finance Tbk, Perusahaan pembiayaan PT Adira Dinamika Fulti Finance Tbk,dalam menangani debitur yang bermaslah biasanya melakukan pendekan persuasif sampai dengan upaya-upaya Hukum, Berdasarkan strategi penanganan Collection dibedakan menjadi:

a. Front End (FE)

b. Back End (BE) Officer,

Strategi penanganan Konsumen OD dibedakan menjadi 3, yaitu :

1. Penanganan Konsumen Berdasarkan Karakter Konsumen (Judgemental)

a. Regular Good

\section{b. Bad Character}

Adapun upaya yang dilakukan perusahaan pembiayaan dalam kegiatan perkreditan terhadap debitur yang mengalami kesulitan untuk memenuhi kewajibannya, yang dilakukan antara lain melalui:

1) Rehabiltasi tanggal jatuh tempo;

2) Restructurisasi pembiayaan;

3) Pelunasan Khusus;

4) Eksekusi Obyek Jaminan Fidusia

Apabila upaya-upaya penyelamatan kredit seperti telah dikemukakan diAtas tidak berhasil, maka penanganan atau upaya penagihan kredit yang terakhir adalah dengan melakukan eksekusi obyek fidusia hingga proses hokum. 


\section{Akibat hukumnya bagi debitur wanprestasi yang mengalihkan obyek jaminan} fidusia ke pada pihak ketiga sedangkan jaminan fidusianya sudah didaftarkan

Dalam upaya menanggulangi pelanggaran dimasyarakat yang dilakukan oleh para debitur yang dapat mengakibatkan kerugian terhadap kreditor,dalam hal ini pemerintah telah mengeluarkan suatu kebijakan hukum pidana dalam bentuk Undang-Undang Republik Indonesia Nomor 42 Tahun 1999 Tentang Jaminan Fidusia. Walaupun perjanjian fidusia merupakan perbuatan privat dalam perdata namun Undang-Undang Jaminan Fidusia juga mengatur perbuatan pidana serta mengatur sanksi pidananya yang terdapat dalam Pasal 35 dan Pasal 36 Undang-Undang Jaminan Fidusia. Itu artinya bahwa sanksi pidana masih dibutuhkan dalam hal privat sekalipun untuk mengatur ketertiban umum dan keamanan masyarakat.

PT Adira Dinamika Multi Finance Tbk sudah sering melakukan upaya hukum dengan melaporkan debitur yang mengalihkan obyek jaminan fidusia ke pihak kepolisian ada beberapa debitur yang sudah di pidana karena perbuatannya tersebut dengan menggunakan pasal 35 atau pasal 36 UU No 42 tahun 1999.Saat dilakukan penyidikan sulit untuk menjerat pihak -pihak yang bermain dalam pengalihan obyek jaminan fidusia seperti pihak yang turut serta mengalihkan dan yang menerima obyek jaminan fidusia karena tidak di sebutkan dalam UU No 42 tahun 1999.

\section{E. PENUTUP}

Pendaftaran Jaminan Fidusia diajukan dalam jangka waktu paling lama 30 hari terhitung sejak tanggal pembuatan akta jaminan fidusia, Jaminan Fidusia lahir pada tanggal yang sama dengan tanggal Jaminan Fidusia dicatat. Sertifikat Jaminan Fidusia ditandatangani secara elektronik oleh Pejabat pada Kantor Pendaftaran Fidusia. Sertifikat Jaminan Fidusia dapat dicetak pada tanggal yang sama dengan tanggal Jaminan Fidusia dicatat.Apabila terjadi kesalahan pengisian data dalam permohonan pendaftaran Jaminan Fidusia yang diketahui setelah sertifikat Jaminan Fidusia dicetak, Penerima Fidusia, kuasa atau wakilnya harus mengajukan permohonan perbaikan sertifikat Jaminan Fidusia kepada Menteri. Permohonan perbaikan sertifikat Jaminan 
Fidusia diajukan dalam jangka waktu paling lama 30 (tiga puluh) hari terhitung sejak tanggal sertifikat Jaminan Fidusia diterbitkan. Persyaratan untuk dapat dilaksanakannya eksekusi terhadap objek jaminan fidusia diatur dalam Peraturan Kapolri No. 8 tahun 2011, untuk melaksanakan eksekusi terhadap objek jaminan fidusia juga di atur di dalam pasal 29 sampai dengan Pasal 34 Undang-Undang Nomor 42 Tahun 1999 Tentang Jaminan Fidusia dan Berdasarkan ketentuan pasal 21 sampai dengan pasal 23 dan pasal 51 Peraturan Otoritas Jasa Keuangan Nomor 29/POJK.05/2014 yang diamandemen dengan POJK 35 tahun 2019 tentang Penyelenggaraan Usaha Perusahaan Pembiayaan.

\section{DAFTAR PUSTAKA}

\section{BUKU}

Bambang Sugono, 2001, Metode Penelitian Hukum, Jakarta : Raja Grafindo.

Burhan Ashshofa. Metode Penelitian Hukum (Jakarta : Rineka Cipta)

H.Salim HS, 2007, Perkembangan Hukum Jaminan di Indonesia, Edisi 1, Jakarta : Raja Grafindo Persada.

H.Tan Komelo,2006,Hukum Jaminan Fidusia, Suatu Kebutuhan yang didambakan, (Bandung : PT. Alumni)

Irma Devita Purnama sari, 2001, Kiat-Kiat Cerdas Mudah Dan Bijak Memahami Masalah HUKUM JAMINAN PERBANKAN" Cet-1(Bandung;Mijan).

Munir Fuady, 1995, Hukum tentang Pembiayaan Dalam Teori dan Praktek (Leasing, Factoring, Modal Ventura, Pembiayaan Konsumen, Kartu Kredit), Bandung : Citra Aditya Bakti.

Purwadi Patrik dan Kashadi, 2004, Hukum Jaminan Edisi Revisi dengan UUHT, Semarang : Fakultas Hukum UNDIP,

Retnowulan Sutantio, 1994, Perjanjian Pembiayaan Konsumen, Dalam Pustaka Peradilan Proyek Pembinaan Tehnis Yustisial Mahkamah Agung R I ,Jakarta.

Ronny Hanitijo Soemitro. Metode Penelitian Hukum dan Jumitri (Yogyakarta :Ghalia Indonesia),

Satjipto Raharjo, 2006, Hukum Dalam Jagat Ketertiban, Jakarta : UKI Press.

Sidharta, 2000, Hukum Perlindungan Konsumen Indonesia, Grasindo, Jakarta.

Soerjono Soekanto dan Sri Mamudji, 2004, Penelitian Hukum Normatif (Jakarta : Rajawali Pres).

Subekti, 1995, Pokok-pokok Hukum Perdata, cet.27 (Jakarta : PT. Intermasa)

Sudikno Mertokusumo, 2010, Mengenal Hukum, Yogyakarta : Universitas Atma Jaya. Surachmad Winarno, 2004, Dasar dan Teknik Research Pengantar Metodelogi Ilmiah (Bandung;CV Tarsito) 


\section{UNDANG-UNDANG}

Kitab Undang-Undang Hukum Perdata

Undang-Undang Nomor 42 Tahun 1999 tentang Jaminan Fidusia

POJK NO 29 tahun 2014, POJK NO 35 tahun 2019 Tentang Tentang Penyelenggaraan Usaha Perusahaan Pembiyaan.

PP No. 21 Tahun 2015 Tentang Tata Cara Pendaftaran Jaminan Fidusia

Peraturan Kapolri No 8 Tahun 2011

Keputusan Presiden Republik Indonesia Nomor 61 Tahun 1988 Tentang Lembaga Pembiayaan

\section{INTERNET}

https://www.hukumonline.com/klinik/detail/lt4ff01dc573ebb/kewajiban-melunasi-utang-walauobyek-jaminan-hilang/

https://irmadevita.com/2016/pembahasan-pp-no-21-tahun-2015-tentang-tata-carapendaftaran-jaminan-fidusia-dan-biaya-ajf-serta-dampaknya-bagi-notaris/ 